\title{
Model Estimasi Suhu Kritis Atas pada Sapi Perah Dara Berdasarkan Manajemen Pakan
}

\section{Model Estimation of High Critical Temperature of Dairy Cattle Based on Feeding Management}

\author{
D. Suherman ${ }^{1}$ dan B.P. Purwanto ${ }^{2}$ \\ ${ }^{1}$ Jurusan Peternakan, Fakultas Pertanian, Universitas Bengkulu \\ ${ }^{2}$ Ilmu Produksi Ternak, Fakultas Peternakan, Institut Pertanian Bogor \\ Corresponding email:
}

\begin{abstract}
A research was conducted in Jakarta and Bogor for two months. The objective of research was to measure effects of critical temperature (air temperature and humidity) on indicated physiological responses for critical temperature of Fries Holland heifers. They were fed twice daily with grass and concentrate. Six dairy heifers were used in the research. The Indicate physiological responses were heart rate and respiration frequency for 14 days. The results showed that the effect of critical temperature on physiogical responses were significantly better on cattle for ANN which for critical temperature in Jakarta and Bogor that with the same and significantly better on cattle with respiration frequency and heart rate in Jakarta and Bogor.
\end{abstract}

Key words: critical temperature, heifer, physiological responses, ANN

\begin{abstract}
ABSTRAK
Penelitian dilakukan di Jakarta dan Bogor selama dua bulan. Tujuan dari penelitian ini adalah untuk mengukur efek suhu kritis (suhu udara dan kelembaban) pada respon fisiologis yang ditunjukkan untuk suhu kritis sapi Fries Holland. Mereka diberi makan dua kali sehari dengan rumput dan konsentrat. Enam sapi dara digunakan dalam penelitian. Indikasi respon fisiologis adalah denyut jantung dan frekuensi respirasi selama 14 hari. Hasil penelitian menunjukkan bahwa pengaruh suhu kritis pada respon fisiologis secara signifikan lebih baik pada sapi untuk JST yang untuk suhu kritis di Jakarta dan Bogor yang sama dan lebih baik pada sapi dengan frekuensi respirasi dan denyut jantung di Jakarta dan Bogor.
\end{abstract}

Kata kunci: suhu kritis, sapi, respons fisiologis, ANN

\section{PENDAHULUAN}

Penampilan produksi ternak sapi perah sangat dipengaruhi oleh lingkungan (klimatologis, nutrisional, manajerial) dan hereditas, karena produksi ternak tersebut merupakan manifestasi dan interaksi antara hereditas dengan lingkungan. Rendahnya produksi erat kaitannya dengan rendahnya mutu pakan dan manajemen pakan serta kurang optimalnya penanganan klimatologis seperti suhu dan kelembaban udara. Hal ini menunjukkan bahwa produksi pada sapi perah FH masih dapat dioptimalkan melalui penentuan suhu kritis dalam kandang dan manajemen pakan.

Lingkungan merupakan salah satu faktor yang mempengaruhi produktivitas ternak sapi perah. Keunggulan genetik seekor ternak sapi perah tidak akan ditampilkan optimal apabila faktor lingkungannya tidak sesuai. Salah satu faktor lingkungan yang menjadi kendala tidak terekspresinya sifat genetik ternak adalah lingkungan mikro (Esmay 1978). Faktor-faktor lingkungan mikro yang menjadi kendala terutama adalah suhu udara, kelembaban udara, radiasi matahari, dan kecepatan angin (Gebremedhin, 1985; Santoso et al., 2003), sehingga perlu upaya pengendalian lingkungan mikro agar produktivitas ternak sapi perah dapat ditingkatkan.

Sapi perah dapat hidup dengan nyaman dan berproduksi secara optimum bila faktorfaktor internal dan eksternal berada dalam batasan-batasan normal yang sesuai dengan kebutuhan hidupnya. Suhu lingkungan merupakan salah satu faktor eksternal yang dapat mempengaruhi kenyamanan dan produktivitas sapi perah. Suhu kritis dan panas lingkungan pada peternakan sapi perah menjadi salah satu masalah utama karena dapat menyebabkan kerugian ekonomi akibat penurunan produktivitas (St-Pierre et et al., 2003). Pada saat akhir abad 19 dan abad 20 ditandai dengan 
meningkatnya rataan temperatur global dari 0,8 menjadi $1,7^{\circ} \mathrm{C}$. Akibatnya terjadi peningkatan rataan temperatur global selama 5 tahun terakhir. Oleh karena itu, diduga terjadi pergeseran kisaran suhu termonetral dan suhu kritis pada sapi perah .

Sebagian besar sapi perah yang ada di Indonesia adalah sapi bangsa Fries Holland $(\mathrm{FH})$, yang didatangkan dari negara-negara Eropa dan memiliki iklim sedang (temperate) dengan kisaran suhu termonetral rendah berkisar $13-18^{\circ} \mathrm{C}$ (McDowell, 1972), 5-25 ${ }^{\circ} \mathrm{C}$ (McNeilly 2001). Kondisi asal iklim tersebut, sapi perah FH sangat peka terhadap perubahan iklim mikro terutama suhu dan kelembaban udara tinggi menyebabkan cekaman panas dan berakibat menurunnya produktivitas. Strategi mengurangi cekaman panas dapat dilakukan dengan perbaikan pakan, perbaikan konstruksi kandang, pemberian naungan pohon dan air minum ad libitum (Velasco et al., 2002).

Penentuan suhu kritis didasarkan pada respon fisiologis, konsumsi pakan, dan produksi sapi perah cukup intensif dilakukan di daerah subtropis. Namun demikian, penentuan suhu kritis yang didasarkan pada respon fisiologi, konsumsi pakan, dan produksi sapi perah yang dipelihara di dataran rendah dan dataran tinggi dari daerah tropis pada usaha peternakan rakyat, khususnya Indonesia, masih belum dilakukan secara menyeluruh serta berkesinambungan. Selain itu hasil penentuan suhu kritis dari daerah subtropis belum tentu cocok diterapkan di daerah tropis, akibat lingkungan mikro yang berbeda sehingga diduga memberikan hasil yang berbeda.

Di daearah tropis, daya tahan ternak terhadap panas merupakan salah satu faktor yang sangat penting agar ternak berproduksi optimal sesuai kemampuan genetis yang dimiliki. Ternak yang tidak tahan terhadap panas, produktivitasnya akan turun akibat dari menurunnya konsumsi pakan. Sementara itu ternak yang tahan terhadap panas dapat mempertahankan suhu tubuhnya dalam kisaran yang normal tanpa mengalami perubahan status fisiologis dan produktivitas (Tyler dan Enseminger, 2006).

Proses mempertahankan suhu tubuh tersebut dikenal dengan proses termoregulasi atau pengaturan panas. Proses ini terjadi bila sapi perah mulai merasa tidak nyaman. Proses termoregulasi pada prinsipnya adalah keseimbangan panas antara produksi panas dan pelepasan panas (Yousef, 1985). Ternak akan memproduksi panas dalam tubuhnya sebagai upaya menghasilkan energi yang diperlukan untuk kehidupannya (beraktifitas dan penyesuaian terhadap lingkungan). Panas yang diproduksi tergantung dari aktifitas ternak dan intake pakan, feed intake dinyatakan dalam TDN yang menunjukkan total bahan pakan dapat dicerna oleh ternak (Rahardja, 2007). Perolehan panas dari energi pakan akan menambah beban panas bagi ternak bila suhu udara lebih tinggi dari suhu nyaman dan sebaliknya kehilangan panas bila suhu udara lebih rendah dari suhu nyaman.

Penelitian mengenai sifat daya tahan panas telah banyak dilakukan pada sapi perah berdasarkan pada sumber panas dari luar tubuh, sedangkan sumber panas dari dalam tubuh seperti pakan belum banyak dilakukan. Panas ini memberikan makna esensial untuk mempertahankan suhu tubuh dan laju metabolisme yang tinggi pada sapi perah, sehingga dapat menghasilkan produktivitas yang normal. Akan tetapi sebaliknya di lingkungan dengan suhu yang tinggi, EKP merupakan tambahan beban panas dan menurunkan produksi (West, 2003; Pennintong dan van Devender, 2004).

Pada tempat-tempat tertentu bagi pengembangan sapi perah $\mathrm{FH}$ di daerah tropik, suhu lingkungan siang hari mencapai $27^{\circ} \mathrm{C}$ selama lebih dari 6 jam. Hal tersebut dapat menyebabkan sapi mengalami suhu kritis dan cekaman panas berkelanjutan sehingga produksi maksimal tidak akan tercapai. Dalam keadaan cekaman panas diperlukan energi tambahan untuk meningkatkan pembuangan panas melalui penguapan kulit dan pernapasan, akibatnya produksi menurun. Oleh karena itu, perlu adanya suatu penelitian tentang penentuan suhu kritis berdasarkan kemampuan produksi dan manajemen pakan di daerah tropik pada dataran tinggi, sedang, dan rendah untuk meningkatkan produksi yang dihasilkan. Penentuan suhu kritis berdasarkan kemampuan produksi dan manajemen pakan pada sapi perah diharapkan sebagai dasar ukuran untuk menentukan respon fisiologis dan kehilangan panas melalui penguapan dari permukaan kulit, sehingga akan memperbaiki keseimbangan panas, selanjutnya akan meningkatkan konsumsi pakan dan produksi.

Suhu dan kelembaban udara berpengaruh langsung terhadap perubahan fisiologi sapi perah, sehingga akhirnya akan berdampak pada produksi. Pada keadaan suhu dan kelembaban tinggi akan terjadi penentuan antara imbangan 
proses perolehan panas (produksi panas metabolisme dan perolehan dari lingkungan) dengan pembuangan panas dalam rangka memelihara tingkat suhu tubuh normal. Semakin tinggi suhu lingkungan di atas Thermoneural zone akan menyebabkan perolehan panas lebih banyak daripada pembebasan panas, akibatnya peningkatan suhu tubuh. Bila suhu tubuh meningkat, akan terjadi usaha ternak untuk mengeluarkan panas dengan cara radiasi, konduksi, konveksi, dan evaporasi, yang mengakibatkan terjadinya peningkatan konsumsi air minum dan menurunkan konsumsi pakan, serta energi yang digunakan untuk mengatur suhu tubuh meningkat. Peningkatan suhu tubuh tersebut akan meningkatkan laju metabolisme dalam sel. Namun adanya pengaturan homeostasi melalui hormonal, akan menurunkan laju produksi panas.

Penelitian ini diharapkan dapat memberikan informasi mengenai penentuan batas suhu kritis sapi perah dara berdasarkan respon fisiologis di dua daerah dengan lingkungan yang berbeda. Informasi mengenai suhu kritis berdasarkan respon fisiologis akan digunakan sebagai dasar pengembangan sapi perah di Indonesia yang memiliki suhu udara panas.

\section{MATERI DAN METODE}

Penelitian dilakukan di laboratorium lapangan, unit produksi ternak perah Departemen Ilmu Produksi dan Teknologi Peternakan Fakultas Peternakan IPB Bogor dan Kebon Pedes Bogor sebagai daerah topografi sedang (400-600 dpl), dan peternakan sapi perah rakyat di Pondok Rangon Jakarta Timur sebagai topografi rendah (200-400 dpl). Lama penelitian dilaksanakan masing-masing daerah selama satu bulan serta dimulai dari bulan Januari 2014 hingga Februari 2014.

Kegiatan penelitian kajian untuk menganalisis penentuan batas suhu kritis sapi perah dara dalam kandang berdasarkan respon fisiologis pada masing-masing waktu dan suhu lingkungan serta berbeda daerah. Enam ekor sapi dara PFH menempati tiap petak kandang. Sapi-sapi dipelihara selama 14 hari, dengan kurun waktu tersebut setiap hari diberikan pakan pada pagi hari pukul 06.00 - 07.00 dan sore hari pukul 15.00 - 16.00 dengan $60 \%$ rumput dan $40 \%$ konsentrat. Selama pengamatan sapi tidak dimandikan.
Rancangan penelitian secara purposive untuk menganalisis penentuan batas suhu kritis sapi perah dara dalam kandang berdasarkan respon fisiologis pada masing-masing waktu dan suhu lingkungan dengan berbeda daerah. Selanjutnya dilakukan pengamatan respon fisiologis pada masing-masing waktu dan suhu lingkungannya, dari pukul 5.00 hingga pukul 20.00 dengan selang waktu pengamatan satu jam.

Parameter yang diamati terdiri atas faktor iklim dan respon fisiologis sapi perah. Faktor iklim yang diukur meliputi suhu udara bola basah dan bola kering (DBT-WBT), kelembaban $(\mathrm{RH})$, kecepatan angin, dan menghitung Temperature Humidity Indeks (THI). Pengamatan suhu udara dan kelembaban dalam kandang dilakukan setiap hari dari pukul 05.00 hingga pukul 20.00 dengan selang waktu satu jam selama 14 hari. Respon fisiologis sapi yang diukur adalah frekuensi pernafasan $(\mathrm{Rr})$ dan denyut jantung (Hr). Pencatatan suhu frekuensi pernafasan (Rr) dan denyut jantung $(\mathrm{Hr})$ dilakukan selama 14 hari dari pukul 05.00 hingga pukul 20.00 dengan selang waktu satu jam.

\section{Metode Pengukuran Parameter}

1. Suhu dan kelembaban udara diukur dengan termometer bola basah dan bola kering. Pengukuran dilakukan di dalam kandang.

2. Indeks suhu kelembaban (THI) dihitung menggunakan rumus Hahn (1985) yaitu : THI $=\mathrm{DBT}+0,36 \mathrm{WBT}+41.2, \mathrm{DBT}=$ suhu bola kering $\left({ }^{\circ} \mathrm{C}\right)$ dan $\mathrm{WBT}=$ suhu bola basah $\left({ }^{0} \mathrm{C}\right)$.

3. Kecepatan angin diukur menggunakan anemometer digital yang diletakkan di dalam kandang. Anemometer di buka selama 15 menit kemudian di baca kecepatan rata-rata tiap detiknya.

4. Denyut jantung diukur dengan menempelkan stetoskop di dekat tulang axilla sebelah kiri (dada sebelah kiri) selama satu menit.

5. Frekuensi pernafasan, diukur setelah pengukuran denyut jantung dengan cara menempelkan stetoskop di dada untuk menghitung inspirasi dan ekspirasi pernafasan selama satu menit.

Analisis data berupa penentuan batas suhu kritis pada sapi dara PFH dalam kandang berdasarkan respon fisiologis dengan waktu pengamatan yang diperoleh dengan berbeda daerah, diuji menggunakan gambar Gambar dan analisis model Artificial Neural Network (ANN) dengan cara program Excel. 


\section{HASIL DAN PEMBAHASAN}

\section{Kondisi Lingkungan Iklim Mikro Daerah Penelitian}

Perubahan-perubahan pada panas lingkungan sangat tergantung dari kondisi udara lingkungan yang meliputi suhu udara, kelembaban udara, radiasi matahari, kecepatan angin, kepadatan kandang, dan karakter pelepasan panas metabolis tubuh ternak (Berman 2008). Hasil pengamatan selama penelitian yang berlangsung dari pukul 05.00 hinggga pukul 20.00, kondisi lingkungan iklim mikro di daerah Bogor dan Jakarta, berupa kisaran suhu udara berkisar antara $22-33^{\circ} \mathrm{C}$ dan $23,50-33,50^{\circ} \mathrm{C}$, kelembaban udara antara $53-91 \%$ dan $56-88 \%$, kecepatan angin antara 0-0,9 m/s dan 0-0,6 m/s, dan nilai THI berkisar antara 70,94-83,92 dan 72,80-84,42 (Gambar 1). Nilai suhu dan kelembaban udara tersebut menunjukkan kondisi lingkungan ternak berpotensi memberikan suhu kritis dan cekaman fisiologis pada sapi dara peranakan FH. Kisaran zona termonetral ternak berada pada suhu udara antara $13-18^{\circ} \mathrm{C}$ (McDowell 1972), 5-25 $\mathrm{C}$ (Jones dan Stallings 1999), suhu udara antara $13-25^{\circ} \mathrm{C}$ dan kelembaban udara antara 50-60\% (McNeilly 2001). Suhu dan kelembaban lingkungan yang ideal bagi penampilan produksi sapi perah peranakan FH akan dicapai pada suhu udara $18,3^{\circ} \mathrm{C}$ dan kelembaban udara 55\% (Sutardi 1981), serta penampilan produksi masih cukup baik bila suhu lingkungan meningkat sampai $21,1^{\circ} \mathrm{C}$ serta suhu kritis sebesar $27^{\circ} \mathrm{C}$ (Sudono et al. 2003).

Kondisi pada pagi hari (pukul 05.0009.00) relatif sama dengan sore hari (pukul 16.00-20.00), baik di daerah Bogor maupun Jakarta. Suhu udara pagi hari relatif sesuai untuk sapi dara FH, akan tetapi kelembaban udara kurang sesuai, karena berada di atas kisaran normal. Pada sore hari, terjadi cekaman udara diakibatkan kelembaban udara. Rataan nilai THI sore hari sebesar 75 di daerah Bogor dan sebesar 76 di daerah Jakarta menunjukkan terjadinya cekaman ringan. Suhu udara pada sore hari menurun, akan tetapi kelembaban udara meningkat. Sementara itu, kecepatan angin pada sore hari relatif belum cukup untuk mengurangi beban panas tubuh ternak. Kelembaban udara tersebut dapat menjadi faktor penghambat proses konveksi dan evaporasi ternak. Bohmanova (2007) menyatakan bahwa kelembaban udara merupakan faktor penghambat proses stress panas pada iklim lembab dan suhu udara kering adalah faktor pembatas stress panas pada iklim kering.

Pada Gambar 1, pukul 05.00 hingga 09.00 kondisi suhu udara, kelembaban udara dan THI berpotensi menyebabkan cekaman ringan. Cekaman lebih disebabkan tingginya kelembaban udara pada pukul tersebut. Berdasarkan nilai suhu udara dan THI tersebut, bagi sapi perah mengindikasikan mengalami suhu kritis. Apabila suhu udara meningkat diatas suhu termonetral sapi akan mulai menderita suhu kritis atau dimulainya menderita cekaman, sehingga mekanisme termoregulasi mulai bekerja terutama dengan cara meningkatkan pernafasan, denyut jantung dan penguapan air melalui kulit. Untuk mengetahui status suhu kritis pada ternak dapat dilakukan dengan mengetahui suhu tubuh yang diestimasikan dari hasil pengukuran suhu rektal dan suhu kulit, sedangkan untuk mengetahui tingkat pembuangan panas tubuh (heat loss) dapat dilakukan dengan mengetahui suhu kulit, frekuensi pernafasan dan denyut jantung (Purwanto 19993). Daerah termonetral bagi ternak merupakan kisaran suhu udara dan THI yang paling sesuai untuk kehidupannya, dimana terjadi metabolisme basal dan hanya terjadi mekanisme pengaturan panas secara sensible dengan menggunakan energi yang paling sedikit. Kisaran suhu udara tersebut tidak menyebabkan peningkatan atau penurunan fungsi tubuh (McDowell 1972; Yousef 1985), terjadinya metabolisme basal pada kisaran suhu termonetral tersebut berarti pula produksi panas tubuh sangat rendah. Kecepatan angin pada pukul 05.00 hingga pukul 07.00 (Gambar 1) sangat rendah dan bernilai $0 \mathrm{~m} / \mathrm{s}$ sehingga angin belum cukup berfungsi untuk membantu pelepasan panas dan mereduksi beban panas tubuh ternak (Yani dan Purwanto 2006).

Pada siang hari (pukul 10.00-15.00), suhu udara dan THI meningkat hingga pukul 13.00 di daerah Bogor dan Jakarta (pukul 12.00), sebaliknya kelembaban udara menurun, akan tetapi kelembaban tersebut tetap pada nilai yang berpotensi memberikan suhu kritis ternak atau cekaman panas, baik di daerah Bogor maupun Jakarta. Nilai rataan THI pada pukul 12.00 dan pukul 13.00 adalah yang tertinggi di daerah Bogor yaitu sebesar 82, tetapi di daerah Jakarta sebesar 84. Hasil nilai rataan THI tersebut mengindikasikan adanya suhu kritis atau cekaman panas pada ternak, hal ini berdasarkan klasifikasi Pennington dan VanDevender (2004) nilai THI tersebut menunjukan terjadinya suhu 
kritis atau cekaman panas sedang pada ternak. Cekaman panas sedang ditandai dengan terjadinya pelepasan tubuh sebanyak $50 \%$ melalui proses respirasi (Berman 2005). Pada kondisi iklim mikro tersebut, harus diperhatikan peternak di Indonesia untuk mengurangi pengaruh iklim mikro dengan beberapa cara yang disarankan oleh Velasco et al. (2002) melalui perbaikan manajemen pakan, imbangan nutrisi, pemberian air minum adlibitum, dan sirkulasi kandang. Usaha lain untuk peningkatan pemahaman efek lingkungan iklim mikro pada siang hari dengan ditandai terjadinya suhu kritis ternak dan cekaman panas menuntut peternak untuk memaksimalkan efek positif dan negatifnya (Coller et al., 2006). Waktu pemberian pakan dan pemberian pakan yang memiliki heat increament relatif rendah dengan berdasarkan suhu kritis ternak disarankan untuk dilakukan bila siang hari ada cekaman iklim panas di daerah pengembangan sapi perah.
Kecepatan angin berfungsi mengalirkan udara yang bersuhu lebih tinggi di sekitar ternak ke tempat yang lain. Selain itu, angin dapat membantu proses konveksi dan evaporasi panas dari tubuh ternak ke lingkungan. Pada pagi menuju siang hari, kecepatan angin meningkat seiring meningkatnya suhu udara, sehingga peningkatan kecepatan angin belum banyak berpengaruh pada penurunan cekaman panas tubuh ternak, sebaliknya sore hari semakin menurun. Rataan kecepatan angin pada siang dan sore hari di daerah Bogor dan Jakarta masih relatif rendah yaitu $0,4 \mathrm{~m} / \mathrm{s}$ dan $0,2 \mathrm{~m} / \mathrm{s}$ serta 0,1 $\mathrm{m} / \mathrm{s}$ dan $0,08 \mathrm{~m} / \mathrm{s}$. Pemberian kecepatan angin 1,12-1.30 m/s akan membantu sapi FH mengatasi suhu kritis ternak atau cekaman panas (Lee dan Keala, 2005). Perpindahan panas dengan konveksi dan evaporasi antara ternak dengan lingkungan dipengaruhi kecepatan angin sebesar $25 \%$. Angin dapat digunakan untuk membantu mereduksi cekaman panas pada ternak (Beede dan Colier, 1986).
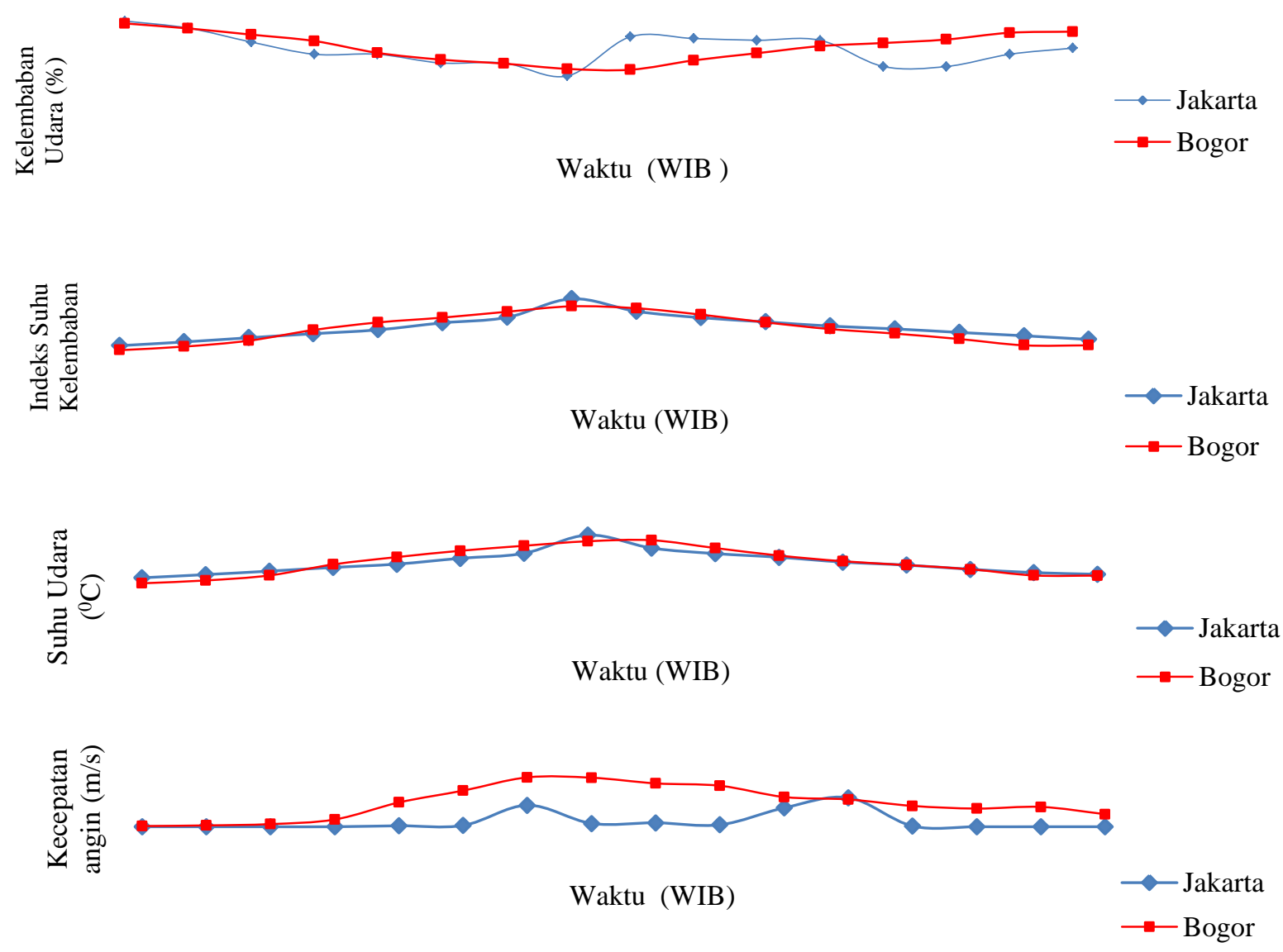

Gambar 1. Rataan Fluktuasi suhu udara (Ta), kelembaban udara (Rh), indeks suhu kelembaban (THI) dan Kecepatan angin (Va) selama Januari-Februari 2014 di Bogor dan Jakarta 


\section{Respon Fisiologis Sapi Perah Dara}

Peningktan frekuensi respirasi seiring juga dengan peningkatan suhu udara dan nilai THI dalam kandang. Pada penelitian ini, frekuensi respirasi harian ternak di daerah Bogor dan Jakarta sebagian masih dalam kisaran normal, yaitu berkisar antara 22-42 dan 22-48. Frekuensi respirasi sapi yang dipelihara pada lingkungan mikro yang nyaman yaitu berkisar antara 10-30 kali/menit (Kelly, 1984). Rataan freukensi respirasi terendah di Bogor dan Jakarta yaitu pada pukul 05.00 pagi ( $29 \mathrm{kali} / \mathrm{menit}$ ) dan (26 kali/menit). Suhu kulit tertinggi pada pukul 12.00 siang ( $38 \mathrm{kali} / \mathrm{menit})$ dan (48 kali/menit) masing-masing untuk Bogor dan Jakarta. Suhu kulit tertinggi di Bogor dan Jakarta terjadi pada sore hari pukul 17.00 (32 kali/menit) dan (34 kali/menit). Peningkatan frekuensi terjadi setelah ternak mulai mengkonsumsi pakan hingga empat jam berikutnya, karena tekanan darah memiliki kekuatan yang sama dengan respirasi (Yang et al., 2000) (Gambar 2). Rataan frekuensi respirasi ternak pada pukul 12.00 siang dan sore hari pukul 17.00 baik di daerah Bogor maupun Jakarta telah mengalami stress panas yang diakibatkan suhu dan kelembaban udara dalam kandang. Peningkatan frekuensi respirasi dapat terjadi pada ternak untuk menjaga keseimbangan panas tubuh saat mengalami cekaman panas tubuh dari hasil metabolisme pakan dan cuaca lingkungan.

Salah satu aktivitas yang dapat dilakukan ternak agar suhu tubuhnya tidak terus menerus naik melalui upaya cara peningkatan laju respirasi (McNelly, 2001). Sistem respirasi pada alveolus dapat mengatur suhu udara dan kelembaban udara yang masuk agar sesuai dengan suhu tubuh (Ganong, 1983). Peningkatan frekuensi respirasi selain terjadi ketika ada peningkatan oksigen yaitu setelah aktivitas, juga ketika ternak terekspos dengan suhu lingkungan dan kelembaban relatif yang tinggi (Kelly, 1984).
Perbedaan suhu tubuh dan lingkungan yang relatif jauh, pada ternak dapat memperlancar mekanisme pelepasan panas saat respirasi melalui mekanisme konveksi dan evaporasi. Konveksi dan evaporasi saat respirasi dapat berfungsi untuk mengeluarkan panas tubuh yang berlebih ke lingkungan. Pada proses metabolisme, tubuh juga menghasilkan $\mathrm{CO}_{2}$ selain panas, maka bila terdapat kenaikan tekanan $\mathrm{CO}_{2}$ diakibatkan kenaikan metabolisme jaringan, ventilasi diransang dan kecepatan ekskresi $\mathrm{CO}_{2}$ paru-paru meningkat sampai tekanan $\mathrm{CO}_{2}$ arteri turun ke normal, menghentikan ransangan. Ganong (1983) menyatakan bahwa kerja mekanisme umpan balik adalah mempertahankan ekskresi $\mathrm{CO}_{2}$ dan menimbulkan keseimbangan.

Hasil penelitian ini, denyut jantung harian ternak di daerah Bogor dan Jakarta sebagian besar masih dalam kisaran normal, yaitu berkisar antara 52-94 kali/menit dan 63-90 kali/menit. Kisaran denyut jantung normal untuk sapi perah antara 50-80 kali/menit (Kelly 1984). Pada pagi hari, peningkatan denyut jantung terjadi satu jam setelah ternak makan untuk daerah Bogor, tetapi denyut jantung ternak di Jakarta relatif konstan. Denyut jantung terendah terjadi pada pukul 07.00 (pagi) dan jam 08.00 (pagi) masing-masing untuk daerah Bogor dan Jakarta, serta meningkat setelah ternak mengkonsumsi pakan dan seiring meningkatnya suhu udara (Gambar 3). Peningkatan pada ternak yang diberi pakan pukul 07.00 masih terjadi hingga tiga jam setelah ternak mengkonsumsi pakan. Konsumsi energi pada sapi mengakibatkan peningkatan produksi panas (Brosh et al. 1998). Kadar energi yang lebih tinggi menyebabkan produksi panas metabolis lebih tinggi dan selanjutnya dapat memicu peningkatan respon fisiologis termasuk denyut jantung.

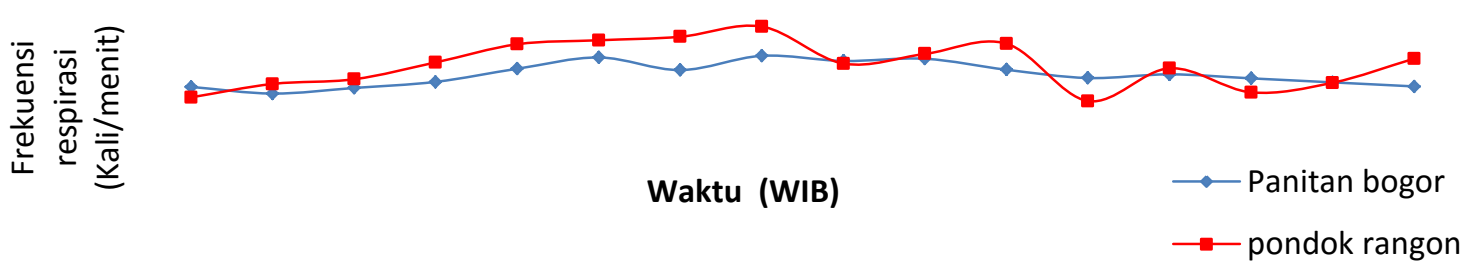

Gambar 2 Rataan fluktuasi frekuensi respirasi (Rr) sapi dara PFH tiap jam dari pukul 05.00 hingga pukul 20.00 antara daerah Bogor dengan Jakarta 
Pada siang hari, keadaan cuaca kandang berpotensi memberikan cekaman cuaca panas. Kondisi tersebut ternak cenderung berbaring sehingga nilai denyut jantung cenderung menurun. Puncak cekaman cuaca panas terjadi 13.00 (siang) dan 12.00 (siang) dengan suhu udara sebesar $32^{\circ} \mathrm{C}$ dan $33^{\circ} \mathrm{C}$, kelembaban udara $60 \%$ dan 57\%, serta nilai THI sebesar 82 dan 84 (cekaman sedang) masing-masing untuk daerah Bogor dan Jakarta. Pada penelitian ini, denyut jantung ternak pada siang hari masih relatif pada kisaran normal yaitu antara 77-84 kali/menit (Bogor) dan 72-83 kali/menit (Jakarta). Saat cekaman panas tertinggi pukul 13.00 siang (Bogor) dan 12.00 siang (Jakarta), rataan denyut jantung ternak penelitian telah mengalami stress panas, berkisar antara 72-82 kali/menit dan 80-83 kali/menit. Kisaran normal denyut jantung yaitu antara 50-80 kali/menit (Kelly, 1984) dan pada saat ada cekaman suhu udara $\left(32^{\circ} \mathrm{C}\right)$, denyut jantung mencapai $79 \mathrm{kali} / \mathrm{menit}$ (Schutz et al., 2009).

Denyut jantung ternak tertinggi di Bogor dan Jakarta terjadi pada sore hari pukul 17.00 (83 kali/menit) dan pukul 16.00 (82 kali/menit). Peningkatan denyut jantung tersebut diakibatkan adanya peningkatan panas metabolisme tubuh, karena ternak baru mengkonsumsi pakan, dan juga disebabkan proses homeostasis ternak setelah terjadi gangguan homeostasis pada siang hari. Mekanisme peningkatan denyut jantung, terjadi adanya peningkatan suhu darah yang secara langsung mempengaruhi jantung dan juga adanya pengaruh penurunan tekanan darah yang berasal dari vasodilatasi peripheral. Perbedaan waktu pemberian pakan memberikan efek yang berbeda terhadap kesesuaian nutrisi bagian peripheral (Nikkhah et al. 2008). Proses terakhir adalah peningkatan jumlah adrenalin dan nonadrenalin yang disekresikan untuk pembentukan energi, dengan disertai sekresi hormon lainnnya dari kelenjar endokrin, sehingga menyebabkan peningkatan denyut jantung (Frandson, 1992). Untuk mengetahui suhu kritis (suhu dan kelembaban udara) di sekitar kandang sapi perah berdasarkan denyut jantung sapi dara dapat digunakan hasil simulasi ANN.

\section{Suhu Kritis dengan Indikator Respon Fisiologis Melalui Simulasi Artificial Neural Network (ANN)}

Penerapan ANN merupakan langkah metode pelatihan propagasi balik yang dilakukan terhadap data-data pelatihan dengan harapan kesalahan (error) terkecil. Setelah dilakukan iterasi berulang-ulang dihasilkan nilai kesalahan yang fruktuasi serta nilai kesalahan yang semakin menurun dari setiap iterasi. Nilai kesalahan yang terkecil pada output prediksi terhadap output target, baik di daerah Bogor maupun Jakarta pada $Y_{\mathrm{p} 1}$ (frekuensi pernafasan) dan $\mathrm{Y}_{\mathrm{p} 2}$ (denyut jantung) yaitu setelah dilakukan iterasi sebanyak 2.100.000/100 (21.000 kali). Masing-masing di daerah Bogor dan Jakarta diperoleh nilai error pada frekuensi pernafasan sebesar 1,177737 dan 1,667858 dan denyut jantung sebesar 1,500040 dan 1,393270. Penurunan nilai error pada frekuensi pernafasan dan denyut jantung untuk daerah Bogor dan Jakarta selama iterasi dapat ditunjukkan pada Tabel 1 dan 2.

Langkah validasi hasil ANN pada frekuensi pernafasan (Rr) dan denyut jantung (Hr)berdasarkan suhu dan kelembaban udara, dengan cara membandingkan data frekuensi pernafasan dan denyut jantung hasil perhitungan ANN dibandingkan dengan hasil pengukuran di lapang. Pelaksanaan validasi dilakukan pada kondisi suhu dan kelembaban udara yang sama antara data hasil perhitungan ANN dan hasil pengukuran di lapang. Selanjutnya validasi dimulai setelah didapatkan nilai error terendah, kemudian dilakukan proses normalisasi kembali, yaitu normalisasi data input $\left(\mathrm{x}_{1}, \mathrm{x}_{2}\right)$, data target $\left(\mathrm{y}_{\mathrm{t} 1}, \mathrm{y}_{\mathrm{t} 2}\right)$ dan hasil prediksi perhitungan ANN $\left(\mathrm{y}_{\mathrm{p} 1}, \mathrm{y}_{\mathrm{p} 2}\right)$.

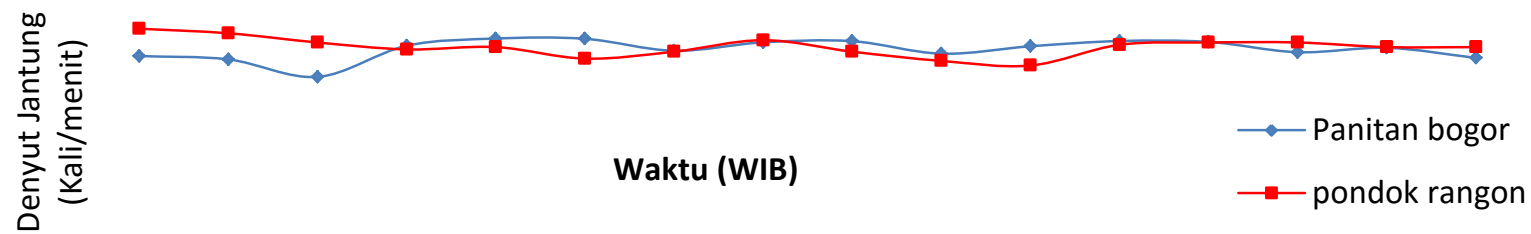

Gambar 3 Rataan fluktuasi denyut jantung (Hr) sapi dara PFH tiap jam dari pukul 05.00 hingga pukul 20.00 antara daerah Bogor dengan Jakarta. 
Tabel 1 Penurunan nilai error berdasarkan tahapan iterasi untuk frekuensi pernafasan $\left(\mathrm{Y}_{\mathrm{p} 1}\right)$, dan denyut jantung $\left(\mathrm{Y}_{\mathrm{p} 2}\right)$ di daerah Bogor

\begin{tabular}{ccc}
\hline Tahap iterasi ke & Error $\mathrm{Y}_{\mathrm{p} 1}$ & Error $\mathrm{Y}_{\mathrm{p} 2}$ \\
\hline 100 & 2,809714 & 2,544321 \\
100.000 & 1,190661 & 1,673544 \\
200.000 & 1,189469 & 1,651128 \\
400.000 & 1,185524 & 1,633988 \\
600.000 & 1,179785 & 1,603280 \\
800.000 & 1,177126 & 1,577698 \\
1.000 .000 & 1,177008 & 1,556823 \\
1.200 .000 & 1,177385 & 1,540282 \\
1.400 .000 & 1,177685 & 1,527407 \\
1.500 .000 & 1,177772 & 1,522079 \\
1.600 .000 & 1,177820 & 1,517351 \\
1.700 .000 & 1,177820 & 1,513136 \\
1.800 .000 & 1,177835 & 1,509355 \\
1.900 .000 & 1,177822 & 1,505946 \\
2.000 .000 & 1,177788 & 1,502855 \\
2.100 .000 & 1,177737 & 1,500040 \\
\hline
\end{tabular}

Nilai validasi menunjukkan kecenderungan hasil perhitungan ANN mendekati hasil pengukuran penelitian lapang dengan rataan nilai persentase error yang rendah, masing-masing untuk daerah Bogor dan Jakarta yaitu $\mathrm{y}_{\mathrm{p} 1}=0,82 \%$ dan $0,95 \%$, dan $\mathrm{y}_{\mathrm{p} 2}=$ $1,50 \%$ dan $1,80 \%$. Pada beberapa titik validasi terjadi perbedaan persentase error yang cukup besar, tetapi masih relatif dalam batasan yang rendah $(\%$ error $<5 \%)$. Hasil nilai tersebut dapat diartikan bahwa nilai prediksi sudah mendekati nilai aktualnya. Nilai persentase error yang rendah menunjukkan bahwa hasil perhitungan
ANN memiliki akuarasi yang tinggi sehingga dapat dijadikan acuan untuk suhu dan kelembaban udara dalam penentuan suhu kritis sapi dara di daerah Bogor dan Jakarta.

Simulasi merupakan teknik penyusunan dari kondisi yang nyata dan kemudian melakukan penelitian pada model yang dibuat dari sistem. Pada simulasi ini dilakukan dengan memperhatikan parameter suhu dan kelembaban udara sebagai penentu suhu kritis dengan respon fisiologis ternak untuk setiap kondisi mulai dari nilai minimum sampai nilai maksimum yang terukur pada penelitian.

Tabel 2 Penurunan nilai error berdasarkan tahapan iterasi untuk frekuensi pernafasan $\left(\mathrm{Y}_{\mathrm{p} 1}\right)$, dan denyut jantung $\left(\mathrm{Y}_{\mathrm{p} 2}\right)$ di daerah Jakarta

\begin{tabular}{ccc}
\hline Tahap iterasi ke & ${\text { Error } \mathrm{Y}_{\mathrm{p} 1}}$ & Error $\mathrm{Y}_{\mathrm{p} 2}$ \\
\hline 100 & 3,232707 & 2,099220 \\
100.000 & 1,668305 & 1,465998 \\
200.000 & 1,651557 & 1,410462 \\
400.000 & 1,617578 & 1,395631 \\
600.000 & 1,621372 & 1,393471 \\
800.000 & 1,631273 & 1,393027 \\
1.000 .000 & 1,640253 & 1,392966 \\
1.200 .000 & 1,650627 & 1,393027 \\
1.400 .000 & 1,655875 & 1,393084 \\
1.500 .000 & 1,658115 & 1,393113 \\
1.600 .000 & 1,660141 & 1,393141 \\
1.700 .000 & 1,661980 & 1,393168 \\
1.800 .000 & 1,663653 & 1,393195 \\
1.900 .000 & 1,665180 & 1,393221 \\
2.000 .000 & 1,666076 & 1,393246 \\
2.100 .000 & 1,667858 & 1,393270 \\
\hline
\end{tabular}


Pada simulasi dengan mengkombinasi nilai input suhu dan kelembaban udara, maka didapatkan variasi nilai output frekuensi pernafasan dan denyut jantung di daerah Bogor dan Jakarta. Berdasarkan hasil simulasi suhu dan kelembaban udara, maka dapat mengetahui berapa respon fisiologis sapi perah pada frekuensi pernafasan dan denyut jantung, tanpa perlu mengukur langsung kepada ternaknya, tetapi cukup melihat suhu dan kelembaban udara yang terukur saat itu, kemudian disimulasikan dengan ANN. Hasil simulasi dapat digunakan untuk mengetahui tingkat respon fisiologis sapi perah $(\mathrm{Rr}$ dan $\mathrm{Hr})$ terhadap perubahan suhu dan kelembaban udara yang berbeda. Hasil simulasi menggunakan ANN tertera pada Tabel 3.

Nilai hasil prediksi dari simulasi ANN yang tertera pada Tabel 3 menunjukkan bahwa semakin meningkat suhu udara dalam kandang, maka semakin meningkat pula frekuensi pernafasan dan denyut jantung sapi perah. Semakin meningkat kelembaban udara baik pada suhu yang sama atau pada suhu yang meningkat pula akan diperoleh hasil prediksi pada frekuensi pernafasan dan denyut jantung sapi yang semakin meningkat. Pada Tabel 3 juga dapat diperoleh korelasi antara suhu dan kelembaban udara dalam kandang dengan tingkat stress sapi berdasarkan frekuensi pernafasan dan denyut jantung. Frekuensi pernafasan sapi pada kondisi normal dapat berlangsung 20-30 kali/menit dan pada kondisi stress dapat mencapai 10 atau 60 kali/menit (Houpt, 2005). Denyut jantung sapi pada kondisi normal berkisar 50-80 kali/menit serta pada kondisi stress berat mencapai 40 atau $120 \mathrm{kali} / \mathrm{menit}$ (Radostits et al., 1999).

Berdasarkan hasil prediksi hasil simulasi ANN, perubahan suhu dan kelembaban udara sangat sensitif mempengaruhi frekuensi pernafasan dan denyut jantung pada sapi perah. Tingkat suhu kritis (cekaman panas) berdasarkan frekuensi pernafasan dan denyut jantung pada suhu dan kelembaban udara yang berbeda baik di daerah Bogor maupun Jakarta dapat dilihat pada Tabel 4.

Berdasarkan hasil prediksi menggunakan ANN, frekuensi pernafasan sapi perah lebih sensitif dipengaruhi perubahan suhu udara dan kelembaban udara dalam kandang. Sapi perah mulai mengalami suhu kritis pada frekuensi pernafasan di daerah Bogor dan Jakarta, masingmasing pada suhu udara $22,5^{\circ} \mathrm{C}$ dengan kelembaban udara $78 \%$ (31,93 kali/menit) dan suhu udara $23,5^{\circ} \mathrm{C}$ dengan kelembaban udara $78 \%$ (30,73 kali/menit). Denyut Jantung mulai terjadi suhu kritis di daerah Bogor dan Jakarta, masing-masing pada suhu udara $24,5^{\circ} \mathrm{C}$ dengan kelembaban $78 \%$ (80,87 kali/menit) dan suhu udara $23,5^{\circ} \mathrm{C}$ dengan kelembaban udara $88 \%$ (88,78 kali/menit).

Tabel 3 Hasil simulasi ANN perkiraan frekuensi pernafasan (Rr) denyut jantung (Hr) pada suhu dan kelembaban udara yang berbeda di daerah Bogor dan Jakarta

\begin{tabular}{cccccccc}
\hline \multicolumn{1}{c}{$\begin{array}{c}\text { Suhu } \\
\text { udara } \\
\left({ }^{\circ} \mathrm{C}\right)\end{array}$} & $\begin{array}{c}\text { Kelembaban } \\
\text { udara }(\%)\end{array}$ & $\begin{array}{c}\text { Frekuensi } \\
\text { pernafasan } \\
(\text { kali/menit })\end{array}$ & $\begin{array}{c}\text { Denyut } \\
\text { jantung } \\
(\text { kali/menit })\end{array}$ & $\begin{array}{c}\text { Suhu } \\
\text { udara } \\
\left({ }^{\circ} \mathrm{C}\right)\end{array}$ & $\begin{array}{c}\text { Kelembaban } \\
\text { udara }(\%)\end{array}$ & $\begin{array}{c}\text { Frekuensi } \\
\text { pernafasan } \\
(\text { kali/menit })\end{array}$ & $\begin{array}{c}\text { Denyut } \\
\text { jantung } \\
(\text { kali/menit })\end{array}$ \\
\hline 23 & 78 & 28,69 & 61,32 & 24 & 88 & 30,10 & 80,57 \\
23 & 76 & 29,65 & 67,90 & 24 & 86 & 28,70 & 80,65 \\
23 & 74 & 32,27 & 67,82 & 24 & 84 & 29,09 & 80,72 \\
26 & 74 & 30,14 & 57,65 & 26,5 & 80 & 30,04 & 80,18 \\
26 & 72 & 30,93 & 55,33 & 26,5 & 78 & 30,90 & 80,50 \\
26 & 70 & 31,84 & 53,37 & 26,5 & 76 & 31,81 & 80,64 \\
29 & 74 & 30,53 & 62,67 & 28,5 & 82 & 26,16 & 80,17 \\
29 & 72 & 31,32 & 62,96 & 28,5 & 80 & 27,06 & 80,28 \\
29 & 70 & 32,20 & 62,03 & 28,5 & 78 & 28,06 & 80,28 \\
31 & 74 & 31,79 & 83,29 & 30 & 82 & 26,52 & 79,56 \\
31 & 72 & 31,90 & 83,28 & 30 & 80 & 28,12 & 79,83 \\
31 & 70 & 32,33 & 83,19 & 30 & 78 & 30,04 & 80,29 \\
32 & 74 & 30,93 & 62,60 & 33 & 82 & 35,98 & 79,54 \\
32 & 72 & 31,70 & 63,14 & 33 & 80 & 37,17 & 79,83 \\
32 & 70 & 32,51 & 63,64 & 33 & 78 & 38,17 & 80,31 \\
\hline
\end{tabular}


Tabel 4 Suhu dan kelembaban udara pada saat sapi perah mulai mengalami suhu kritis (cekaman panas) dengan indikator frekuensi pernafasan ( $\mathrm{Rr}$ ) denyut jantung $(\mathrm{Hr})$ di daerah Bogor dan Jakarta

\begin{tabular}{cccccc}
\hline $\begin{array}{c}\text { Suhu udara } \\
\left({ }^{\circ} \mathrm{C}\right)\end{array}$ & $\begin{array}{c}\text { Kelembaban } \\
\text { udara } \\
(\%)\end{array}$ & $\begin{array}{c}\text { Indikator } \\
\text { cekaman } \\
\text { panas }\end{array}$ & $\begin{array}{c}\text { Suhu udara } \\
\left({ }^{\circ} \mathrm{C}\right)\end{array}$ & $\begin{array}{c}\text { Kelembaban } \\
\text { udara } \\
(\%)\end{array}$ & $\begin{array}{c}\text { Indikator } \\
\text { cekaman } \\
\text { panas }\end{array}$ \\
\hline 22,50 & 78 & $\mathrm{Rr}$ & 23,5 & 78 & $\mathrm{Rr}$ \\
23 & 74 & $\mathrm{Rr}$ & 23,5 & 88 & $\mathrm{Hr}$ \\
24 & 74 & $\mathrm{Rr}$ & 24 & 88 & $\mathrm{Rr}$ dan $\mathrm{Hr}$ \\
24,50 & 78 & $\mathrm{Hr}$ & 25 & 80 & $\mathrm{Rr}$ \\
25 & 74 & $\mathrm{Rr}$ & 25,5 & 82 & $\mathrm{Hr}$ \\
25 & 70 & $\mathrm{Hr}$ & 26 & 78 & $\mathrm{Rr}$ \\
26 & 74 & $\mathrm{Rr}$ & 26,5 & 80 & $\mathrm{Hr}$ \\
27 & 74 & $\mathrm{Rr}$ & 27 & 76 & $\mathrm{Rr}$ \\
28 & 74 & $\mathrm{Rr}$ & 27 & 78 & $\mathrm{Hr}$ \\
28 & 70 & $\mathrm{Hr}$ & 28 & 74 & $\mathrm{Rr}$ \\
29 & 74 & $\mathrm{Rr}$ & 28,5 & 78 & $\mathrm{Hr}$ \\
30 & 74 & $\mathrm{Rr}$ & 29 & 74 & $\mathrm{Rr}$ \\
30,50 & 68 & $\mathrm{Hr}$ & 30 & 78 & $\mathrm{Rr} \mathrm{dan} \mathrm{Hr}$ \\
31 & 60 & $\mathrm{Hr}$ & 31 & 78 & $\mathrm{Rr} \mathrm{dan} \mathrm{Hr}$ \\
31 & 74 & $\mathrm{Rr}$ & 32 & 82 & $\mathrm{Rr}$ \\
32 & 74 & $\mathrm{Rr}$ & 33 & 78 & $\mathrm{Hr}$ \\
32 & 60 & $\mathrm{Hr}$ & 33 & 88 & $\mathrm{Rr}$ \\
\hline
\end{tabular}

Hasil analisis menggunakan ANN untuk prediksi tingkat stress (suhu kritis) sapi perah berdasarkan perubahan suhu dan kelembaban udara dalam kandang lebih tahan terhadap panas bila dibandingkan dengan persyaratan kondisi lingkungan sapi perah yang nyaman yaitu pada suhu udara $5-21^{\circ} \mathrm{C}$ dan $\mathrm{RH}$ sebesar $50-75 \%$ (Smith 2002; Sudono et al. 2003). Suhu kritis di daerah subtropis yang menyebabkan penurunan produksi susu pada bangsa sapi Holstein dan Jersey adalah $21-25^{\circ} \mathrm{C}$, Brown Swiss adalah 30$32^{\circ} \mathrm{C}$, dan Brahman adalah $38^{\circ} \mathrm{C}$ (Sainbury dan Sainsbury, 1982). Hal tersebut menunjukkan bahwa sapi perah telah beradaptasi terlebih dahulu dengan lingkungan dan secara genetik sapi perah peranakan FH tahan terhadap kondisi yang lebih panas. Pengaruh peningkatan kelembaban udara sangat mempengaruhi frekuensi pernafasan sapi perah bila dibandingkan dengan perubahan denyut jantung. Peningkatan suhu udara sangat mempengaruhi Frekuensi pernafasan dibandingkan perubahan denyut jantung. Pada suhu udara yang lebih rendah $\left(22,5-23,5^{\circ} \mathrm{C}\right)$, frekuensi pernafasan sapi perah lebih sensitif terkena stress akibat perubahan kelembaban udara dibandingkan dengan denyut jantung.

\section{KESIMPULAN}

1. Artificial Neural Network (ANN) dapat digunakan untuk menentukan suhu kritis berdasarkan peubah suhu dan kelembaban udara di dalam kandang sapi perah $\mathrm{PFH}$ terhadap respon fisiologisnya dengan indikator frekuensi pernafasan dan denyut jantung.

2. Peningkatan kelembaban dan suhu udara yang sama dan suhu udara berbeda sangat mempengaruhi terhadap suhu kritis pada sapi perah. Peningkatan suhu udara sangat mempengaruhi Frekuensi pernafasan dibandingkan perubahan denyut jantung. Pada suhu udara yang lebih rendah $\left(22,5-23,5^{\circ} \mathrm{C}\right)$, frekuensi pernafasan sapi perah lebih sensitif terkena stress akibat perubahan kelembaban udara dibandingkan dengan denyut jantung.

3. Sapi perah mulai mengalami suhu kritis pada frekuensi pernafasan di daerah Bogor dan Jakarta, masing-masing pada suhu udara $22,5^{\circ} \mathrm{C}$ dengan kelembaban udara $78 \%$ dan suhu udara $23,5^{\circ} \mathrm{C}$ dengan kelembaban udara $78 \%$. Denyut Jantung mulai terjadi suhu kritis di daerah Bogor dan Jakarta, masing-masing pada suhu udara $24,5^{\circ} \mathrm{C}$ dengan kelembaban $78 \%$ dan suhu udara $23,5^{\circ} \mathrm{C}$ dengan kelembaban udara $88 \%$. 


\section{DAFTAR PUSTAKA}

Beede, D.K., R. J. Coolier. 1986. Potential nutritions for intensive managed cattle during thermal stress. J Anim Sci. 62: 543.

Berman, A. 2003. Effect of body surface area estimates on predicted energy requirements and heat stress. J Dairy Sci. 86: $3605-3610$

Berman, A. 2005. Estimates of heat stress relief needs for Holstein dairy cows. J Anim Sci 83: 1377-1384.

Berman, A. 2008. Increasing heat stress relief produced by coupled coat wetting and forced ventilation. J Dairy Sci. 91: 45714578.

Berman A. 2010. Forced heat loss from body surface heat flow to body surface. J Dairy Sci 93:242-248.

Bohmanova, J., I. Misztal, J. B. Cole. 2007. Temperature-humidity indices as indicators of milk production losses due to heat stress. J Dairy Sci. 90: 1947-1956.

Brosh, A., Y. Aharoni, A. A. Degen, D. Wright, and B. A. Young. 1998. Effects of solar radiation, dietary energy, and time of feeding on thermoregulatory responses and energy balance in cattle in a hot environment. Journal of Animal Science, 76(10): 2671-2677.

Collier, R. J., G. E. Dahl, M. J. VanBaale. 2006. Major advances associated with environmental effects on dairy cattle. J Dairy Sci. 89: 1244-1253.

Esmay, M. L. 1982. Principle of Animal Environmental. Connecticut: AVI Publishing Company Inc.

Frandson, R. D. 1992. Anatomi dan Fisiologi Ternak. Srigandono B, Praseno K, penerjemah; Yogyakarta: Gadjah Mada University Press.

Ganong, W.F. 1983. Review of Medical Physiology. Ed ke-11. California: Lange Medical Publication.
Gebremedhin, K. G. 1985. Heat Exchange Between Livestock and Environment. Dalam: Yousef, M. K., editor. Stress Physiology of Livestock. Volume ke-1, Basic Principle. Florida: CRC Press Inc.

Hahn, G. L. 1999. Dynamic responses of cattle to thermal heat loads. J Anim Sci 77: 10-20

Jones, G.M., C. C. Stallings. 1999. Reducing heat stress for dairy cattle. Virginia Cooperative Extension. Publication Number 404-420. http://www.ext.edu/index.html. Oktober 2005].

Kelly, W.R. 1984. Veterinary Clinical Diagnosis. London: Bailliere Tindall.

Kusumadewi, S. 2003. Artificial Intelligence (Teknik dan Aplikasinya). Graha Ilmu, Yogyakarta.

Lee, C. N, N. Keala. 2005. Evalution of cooling system to improve lactating Holstein cows comfort in the sub-tropics. J Anim Sci. 82: 128-136.

Marcillac-Embertson, N. M., P. H. Robinson, J. G. Fadel, and F. M. Mitloehner. 2009. Effects of shade and sprinklers on performance, behavior, physiology, and the environment of heifers. Journal of Dairy Science, 92(2): 506-517.

McDowell, R. E. 1972. Improvement of Livestock Production in Warm Climate. WH Freeman and Co. San Fransisco.

McNeilly, A. S. 2001. Reproduction, fertility, and development. CSIRO Publishing 13:583590.

Nikkhah, A., C. J. Furedi, A. D. Kennedy, G. H. Crow, and J. C. Plaizier. 2008. Effects of feed delivery time on feed intake, milk production, and blood metabolites of dairy cows. Journal of dairy science, 91(11): 4249-4260.

Pennington, J.A., K. VanDevender. 2004. Heat Stress in Dairy Cattle. http://www.uaex.edu/other areas/publication/html [19 Mei 2004]. 
Purwanto, B. P., T. Matsumoto, F. Nakamasu, T. Ito, and S. Yamamoto. 1993. Effect of standing and lying behaviors on heat production of dairy heifers differing in feed intake levels. Asian-Australasian Journal of Animal Sciences. 6(2): 271274.

Rahardja, D. P. 2007. Ilmu Lingkungan Ternak. Makassar: Citra Emulsi.

Sainsbury, D., Sainsbury. 1982. Livestock Health and Housing. English Language Book Society and Bailliere Rudall, London.

Santoso, A. B., A. Sudono, B. P. Purwanto, and W. Manalu. 1996. Pengaruh Lingkungan Mikro terhadap Respons Fisioologi Sapi Dara Peranakan Fries Holland (Doctoral dissertation, Thesis. Program Pascasarjana, IPB, Bogor).

Schutz, K.E., N. R. Cox, L. R. Matthews. 2008. How important is shade to dairy cattle? Choice between shade or lying following different levels of lying deprivation. Appl Anim Behav Sci. 114:307-318.

Schutz, K. E., A. R. Rogers, N. R. Cox, C. B. Tucker. 2009. Dairy cows prefer shade that offers greater protection against solar radiation in summer: shade use, behavior, and body temperature. Appl Anim Behav Sci. 116:28-34.

Schütz, K. E., A. R. Rogers, Y. A. Poulouin, N. R. Cox, and C. B. Tucker. 2010. The amount of shade influences the behavior and physiology of dairy cattle. Journal of dairy science, 93(1): 125-133.

Schütz, K. E., A. R. Rogers, N. R. Cox, J. R. Webster, and C. B. Tucker. 2011. Dairy cattle prefer shade over sprinklers: Effects on behavior and physiology. Journal of dairy science, 94(1): 273-283.

Sudono, A., R. F. Rosdiana, B. S. Setiawan. 2003. Beternak Sapi Perah Secara
Intensif. Cetakan ke-2. Agro Media Pustaka, Bogor.

Sutardi, T. 1981. Sapi Perah dan Pemberian Makanannya. Bogor: Departemen Ilmu Nutrisi dan Makanan Ternak, Fakultas Peternakan, Institut Pertanian Bogor.

Tyler, H. D., M. E. Ensrminger. 2006. Dairy Cattle Science. Pearson edution, Inc. Upper Saddle River, New Jersey.

Velasco, N.B., J. A. Arguzon, J. I. Briones. 2002. Reducing heat stress in dairy cattle: Phlippines. International Training on Strategies for Reducing Heat Stress in Dairy Cattle. Taiwan Livestock Research Institute (TLRI-COA) August 26-31, 2002, Tainan, Taiwan, ROC.

West, J. W. 2003. Effects of heat stress on production in dairy cattle. J Dairy Sci. 86:2131-2141.

Wheelock, J. B., R. P. Rhoads, M. J. VanBaale, S. R. Sanders, and L. H. Baumgard. 2010. Effects of heat stress on energetic metabolism in lactating Holstein cows. Journal of dairy science, 93(2): 644-655.

Yani, A., B. P. Purwanto. 2006. Pengaruh iklim mikro terhadap respon fisiologis sapi peranakan Fries Holland dan modifikasi lingkungan untuk meningkatkan produktifitasnya. Med Pet. 29 (1):35-46.

Yang, C. C, T. B. Kuo. 2000. Impact of pulse pressure on the respiratory-related arterial pressure variability and its autonomic control in the rat. Pflugers Arch 439: 772780.

Yousef, M. K. 1984. Stress Physiology of Livestock. Volume I, Basic Principle. Florida: CRC Press Inc.

Yousef, M. K. 1985. Thermoneutral Zone. In: Stress Physiology of Livestock. Volume II, Basic Principle. Florida: CRC Press Inc. 